\title{
CORRUPTION PERCEPTIONS AND ENTREPRENEURIAL INTENTIONS IN A TRANSITIONAL CONTEXT-THE CASE OF RURAL BULGARIA
}

\author{
DIANA TRAIKOVA \\ External Environment for Agriculture and Policy Analysis \\ Leibniz Institute of Agricultural Development in Transition Economies (IAMO) \\ Halle (Saale), Germany \\ Theodor-Lieser Str. 2, 06120 Halle (Saale), Germany \\ traikova@gmail.com \\ TATIANA S. MANOLOVA \\ Management, Bentley University, Waltham, MA, USA \\ JUDITH MÖLLERS \\ External Environment for Agriculture and Policy Analysis \\ Leibniz Institute of Agricultural Development in Transition Economies (IAMO) \\ Halle (Saale), Germany \\ GERTRUD BUCHENRIEDER \\ Institute of Agricultural and Nutritional Sciences \\ Martin-Luther-University Halle-Wittenberg (MLU) \\ Halle (Saale), Germany \\ TUM School of Life Sciences Weihenstephan \\ Technical University Munich (TUM), Freising, Germany \\ Received September 2016 \\ Revised March 2017 \\ Published September 2017
}

\begin{abstract}
In this study, we augment Ajzen's Theory of Planned Behavior (TPB) with an institutional embeddedness logic to develop and test a mediated model of the effects of perceived corruption on attitudes, social norms and perceived behavioral control, which in turn determine entrepreneurial intentions. We test our three hypotheses on a sample of 231 aspiring entrepreneurs seeking to start a non-farm business in three rural regions of Bulgaria. In our exploratory case study, we find that corruption perceptions are partially mediated by entrepreneurial attitudes and perceived control, but not by social norms. Corruption perceptions are positively associated with entrepreneurial intentions,
\end{abstract}

This is an Open Access article published by World Scientific Publishing Company. It is distributed under the terms of the Creative Commons Attribution 4.0 (CC-BY) License. Further distribution of this work is permitted, provided the original work is properly cited. 
indicative of the deeply rooted social acceptance of corruption in many transition economies. Theoretical, practitioner and public policy implications are discussed.

Keywords: Corruption perceptions; entrepreneurial intentions; mediation; TPB; transition economies; rural entrepreneurship.

\section{Introduction}

In the latest Transparency International's Corruption Perceptions report (Transparency International, 2016) the transition economies in Central and Eastern Europe ranked from 29th (Poland) to 95th (Kosovo) among the 176 countries included in the report. Although significant heterogeneity in cultural norms and business practices does exist, corruption is widespread and deeply rooted in the cultural norms of many of these economies (Dimitrova-Grajzl et al., 2012; Grodeland and Aasland, 2011; Lee and Guven, 2013).

Corruption is typically defined as the abuse of public power for private benefit, while bribery is the manifestation of corruption in informal microeconomic transactions. Corruption increases the direct and indirect costs of doing business, magnifies uncertainty and misaligns economic incentives, thereby discouraging economic value creation and growth-oriented economic activity such as innovation and entrepreneurship (Aidis et al., 2008). Not surprisingly, the antecedents and effects of corruption have garnered increased attention by both scholars and policy makers.

Most of the current research on corruption in the context of entrepreneurship focuses on nascent or already established entrepreneurs. Prior studies have explored topics such as the effect of corruption on the types of economic activity pursued by nascent entrepreneurs or the effect of corruption on new venture performance (Timofeyev and Yan, 2013; Tonoyan et al., 2010). Less understood is the effect of perceived corruption on the individual's ex-ante entrepreneurial intentions, when opportunities are recognized and a decision is made whether to pursue intentions or not (van der Zwan et al., 2011). Perceived corruption can take different cognitive paths and lead to different outcomes. On the one hand, high levels of perceived corruption may be associated with high risks and costs of engaging in economic activity, thus decreasing the perceived feasibility of the envisioned venture, thereby discouraging entrepreneurial intentions (Griffiths et al., 2009). On the other hand, high levels of perceived corruption may be associated with opportunities to engage in rent-seeking, unproductive entrepreneurial activity, thus increasing the perceived desirability of entrepreneurial activity and encouraging positive attitudes and entrepreneurial intentions (Baumol, 1990). Finally, high levels of perceived corruption may be associated with a "greasing" mechanism of facilitating payments to circumvent cumbersome regulation (Méon and Sekkat, 2005; Méon and Weill, 2010), thus rendering the desired venture as easier to achieve and encouraging entrepreneurial intentions. Therefore, our contention is that to better understand the effect of corruption on entrepreneurial intentions, we need to trace how corruption perceptions are mediated by the TPB's three-pronged mechanism of entrepreneurial attitudes, social norms and perceived behavioral control (Ajzen, 1991). This is the focus of our investigation. 
We link perceived corruption and entrepreneurial intentions in an exploratory case study from rural Bulgaria, providing unique empirical evidence from a typical postsocialist country. Bulgaria was hard hit by the "shock therapy" and the institutional hiatus of the transition period and is plagued by rampant petty corruption (Manev and Manolova, 2010). Previous studies of corruption in Bulgaria paint a grim picture of stable entrenchment of bribing and bending the law practices (Stoyanov et al., 2014; Vorley and Williams, 2015). According to the Global Corruption Barometer, barely 15 percent of Bulgarians report it is socially acceptable to report acts of corruption, compared to 58 percent of the respondents in older EU member states (Pring, 2016). We specifically focus on a sample of individuals considering non-farm businesses to complement or substitute their farm livelihoods. A number of European Union programs have been targeted at stimulating entrepreneurial initiatives to revive regional economic development (European Commisson, 2015). Unfortunately, these subsidies have been often mismanaged, with 'serious allegations of irregularities and suspicions of fraud and conflicts of interest in the award of contracts' (Waterfield, 2008). Thus, the case of individuals in rural regions who are plagued, but also tempted by corruption, offers the rare opportunity to explore the multiple cognitive mechanisms through which corruption perceptions influence entrepreneurial intentions.

To explore the effect of corruption on the formation of entrepreneurial intentions, we combine Ajzen's (1991) TPB with an institutional embeddedness logic (North, 1990; Welter and Smallbone, 2011). More specifically, we represent corruption perceptions as a background factor mediated through Ajzen's classical intention antecedents (attitudes, social norms and perceived control). Our approach recognizes that any entrepreneurial behavior is situated in, and cannot be disentangled from, its institutional context (North, 1990), and follows the call of Liñán and Fayolle (2015) for deeper investigation of the role of institutions in the formation of entrepreneurial intentions.

Our study makes a threefold contribution. First, we contribute to the literature on the economic effect of corruption (Aidt, 2003; Harbi and Anderson, 2010) by examining the ex-ante impact of perceived corruption on entrepreneurial intentions. Second, we contribute to the literature on entrepreneurial intentions and particularly to the strand investigating the background factors affecting entrepreneurial attitudes, social norms and perceived behavioral control (Kibler, 2012; Liñán and Chen, 2009; Stuetzer et al., 2014; Zapkau et al., 2015; Zhao et al., 2005). Perceived corruption is assumed to be an important contextual factor in which entrepreneurial intentions are embedded. We contribute to the discussion on the importance of background factors such as corruption, and how they are mediated in the process of intention formation. Third, most empirical studies measure corruption utilizing country-level corruption indices from secondary sources. In contrast, we work with unique hand-collected survey data, which capture respondents' first-hand accounts of corruption at a high-level of granularity.

The paper proceeds as follows. We start by discussing the link between corruption and entrepreneurship in a transitional economy context, after which we develop our theoretical model and hypotheses. We then present our data and methodology and report the results 
from hypothesis testing. We conclude by discussing the findings of the case study and possible theoretical, practitioner, and public policy implications.

\section{Theoretical Background and Hypotheses}

\subsection{Formal and informal institutions in transition economies: The role of corruption}

Institutions are widely accepted systems of practice, technologies and rules of social interaction that are normatively established in a society. Therefore, behaviors contrary to such practices, technologies and rules could be socially disapproved and even sanctioned to ensure compliance (Lawrence et al., 2002). In short, institutions are mental constructs that guide the actors' understanding of social phenomena and thus, set "the rules of the game" (North, 1990). Scholars of institutional theory argue that all strategic and economic activity is embedded in a social and normative context, and such a context motivates organizations and individuals to conform to social rules and expectations to be accorded legitimacy and support, or "a social license to operate" (Engle et al., 2011; North, 1990; Welter, 2011).

Scott (1995) proposes a typology of formal and informal institutions, classifying them into regulatory, normative and cognitive categories. Regulatory institutions refer to the system of formally enacted laws and regulations. Less formal, but equally important, are normative institutions, established by professional and trade associations to regulate the conduct of their members. Cognitive institutions are informal, highly persistent cultural beliefs and values governing appropriate behavior in social interaction, which are learned through living and growing in a community. Differences in institutional arrangements and in the level of economic development yield different rates and types of entrepreneurial activity (Stenholm et al., 2013; Wennekers et al., 2010). In the context of interest to our study, some post-socialist economies exceed the entrepreneurship rate of developed countries (Cieślik and van Stel, 2014). In the case of Bulgaria, national statistics indicate an entrepreneurship rate of 11.3 percent in 2008, the year closest to our study (NSI, 2009).

Despite the differences in institutional arrangements and rates of entrepreneurial activity across the transitional economies in Central and Eastern Europe, they are all, to a certain extent, plagued by the mismatch between formal and informal institutions. This is because formal institutions, to a large degree, have been adapted to the traditions of Western democracies, while cultural practices still bear the imprint of the socialist past (Aidis et al., 2008). In Bulgaria, for example, formal institutions (laws and regulations) have been speedily synchronized with EU policies and directives. However, the grip of the formal institutions has been slow to take hold, partly because of the government's insufficient and inconsistent enforcement efforts, and partly because of the dominant economic actors themselves, who have not been especially interested in establishing a regime of the "rule of law." The result is that the Bulgarian post-socialist business environment is characterized by a general distrust toward the state as a political and economic actor, reliance on personal contacts, bribery, informality and tax evasion (Estrin et al., 2013; Grodeland and Aasland, 2011; Stoyanov et al., 2014). 
When formal institutions are not effective (e.g., the laws are not enforced), people turn to their habitual behavior, which has proven to work in the past (Estrin and Mickiewicz, 2011; Welter and Smallbone, 2011). Grodeland and Aasland (2011) conducted a mixed method survey in seven post-socialist countries in Europe on the use of corruption practices. Their findings reveal that individuals habitually avoid formal institutions and rely on evasion and corrupt practices, even when there is an effective and well-functioning legal alternative. Once corrupt acts are allowed to persist without sanctions over a sufficiently long period of time, they become "normalized" (Ashforth and Anand, 2003), i.e. socially accepted, even if their morality is questionable.

\subsection{Corruption and entrepreneurial activity}

There is an ongoing debate in the literature about the consequences of corruption for economic growth (naturally linked to entrepreneurship) and development. Some scholars argue that in the face of a restrictive regulatory environment, entrepreneurs can circumvent clumsy administrational procedures by offering a bribe and so increase the efficiency of their ventures by sealing deals which would not have happened otherwise (Blackburn et al., 2006; Budak and Rajh, 2014; Levy, 2007). This rationale is known as the 'greasing' argument. In contrast, the 'sanding' argument posits that corruption not only reduces investment (Rock and Bonnett, 2004) and has detrimental effects on human capital accumulation (Reinikka and Svensson, 2004), but also functions like a progressive tax, hurting companies more and more as they grow bigger (Estrin et al., 2013; Hellman et al., 2000).

Empirical evidence is inconclusive. For example, a meta-analytical review covering 41 studies reported the negative effects of corruption on growth prevail over the positive (Campos et al., 2010) while another one, covering 43 countries, found strong support in favor of the 'greasing' argument (Dreher and Gassebner, 2013). Some scholars see the explanation for such puzzling results in the quality of institutions (Dejardin and Laurent, 2014; Dreher and Gassebner, 2013; Méon and Weill, 2010). They claim although strict regulations reduce entrepreneurial activity in the absence of corruption, this negative impact becomes less pronounced with more corruption.

With respect to the effect of corruption on entrepreneurial intentions, Heuer and Liñán (2013), in their study of 1356 business students, found a moderate, but significant negative effect of restrictive regulations on the start-up intent. They explained this finding with the possible link between stringent regulation and corruption. Similarly, Griffiths et al. (2009), utilizing a sample of 1473 individuals across ten countries, report a negative effect of their governmental corruption index on entrepreneurial intentions. Thus, there is some empirical evidence documenting the effect of corruption, as captured by macro-level indices (based on aggregated expert opinions), on individual entrepreneurial intentions.

Less is known about the effect of an individual's perceived level of corruption and his or her entrepreneurial intentions. The perceived level of corruption may differ from the level of corruption reported in macro indices, and from corruption reality. Melgar et al. (2010), in their 33-country study, documented that perceived corruption levels were very 
high in post-socialist countries, particularly among women, poor people and the selfemployed. Olken (2009), in his study of the relationship between corruption perceptions and corruption reality in rural Indonesia, documented the respondents' perceptions were significantly affected by the villages' ethnic heterogeneity and their social capital. In other words, individual perceptions of corruption are shaped by personal experiences, predispositions and biases, and enacted in subsequent behavior. In the next section, we elaborate on the specific mechanisms through which perceived corruption is translated into entrepreneurial intentions.

\subsection{Conceptual model and hypotheses}

To explain how corruption may affect the formation of entrepreneurial intentions, we turn to Ajzen's TPB. It has been extensively tested for the assumed causality direction (Webb and Sheeran, 2006) and validated as a robust theory for the prediction of any intentional behavior (see, for example, the recent longitudinal study by Kautonen et al., 2013). TPB has been successfully tested for robustness in different cultural settings, including postsocialist contexts (Moriano et al., 2012). Thus, it provides a suitable and solid theoretical base for our research endeavor.

According to the TPB, a person's behavior is preceded by the intention to perform a certain action. The intention indicates how people are 'willing to try [and] how much effort they are planning to exert, in order to perform the behavior' (Ajzen, 1991). In turn, the intention is predetermined by the person's attitude toward the outcome of the behavior, the perceived subjective norms, i.e. normative institutions, surrounding the behavior and its outcome, as well as the perceived behavioral control over the action (Ajzen, 1991; Fishbein and Ajzen, 2010b). Thus, TPB posits three independent determinants are sufficient to predict any intention and planned behavior. Attitude refers to the disposition to respond with some degree of favorableness or unfavorableness to the planned behavior (Fishbein and Ajzen, 2010b). Norms express the person's perception that one's important, others prescribe, desire, or expect the performance or non-performance of the planned behavior. Perceived behavioral control is defined as the extent to which people believe they are capable of performing a given behavior, and that they have control over its performance. This intention antecedent is assumed to take into account the availability of information, skills, opportunities and other resources required to perform the behavior as well as possible barriers or obstacles that may have to be overcome.

Regarding entrepreneurial intentions, the TPB predicts that having a positive attitude toward the start-up, perceiving the support of the important peers and believing it is possible to handle the obstacles associated with an entrepreneurial start-up are positively linked to a stronger intention to found a new venture. All remaining possible determinants of the intention are assumed to have only indirect effect (they are mediated) through these three antecedents. (Ajzen, 1991) calls them 'background factors.' Background factors only influence entrepreneurial intention if they are actually perceived and valued by the individual. In the TPB, these background factors are represented by the individual's beliefs, which reflect the information people have about a given issue or behavior (Fishbein and 
Ajzen, 2010a). Beliefs are not innate, but acquired in daily encounters with the real world. An individual's beliefs may be inaccurate or biased, but that is of no consequence for the prediction and explanation of the intention. What matters is their content. From this backdrop, we propose a conceptual model, in which the corruption perception (as manifestation of corruption-related beliefs) is mediated through all three intention antecedents (attitudes, social norms and perceived behavioral control) to influence the entrepreneurial intent. The conceptual model is presented in Fig. 1. The rationale for hypothesizing corruption as a background factor mediated through all three antecedents follows below.

Attitudes mediate corruption perceptions through the subjective cost-benefit estimation of starting a firm. This is closely related to identifying potential business opportunities, assessing their expected benefits and costs, and deciding which of them to pursue or not. On the one hand, if individuals believe the corrupt environment is supportive of the realization of certain desired outcomes they expect from the envisioned start-up (e.g. additional income, less workload, more flexibility, personal satisfaction), they will develop a more pronounced positive attitude toward the start-up. This will strengthen their founding intention. If, on the other hand, potential founders have a rather uneasy feeling because of the perceived corrupt environment (e.g. fear of being caught if bribing or conflict with the personal moral code), they may develop a negative attitude toward the entrepreneurial idea, which would in turn weaken their intention. This is consistent with Collier's (2002) model of corruption as an institutional choice, which consists of both internal (agency) and external (structural) worlds. The internal world constitutes the agent's (in our case, aspiring entrepreneur's) decisionmaking process as a rational choice based on cost-benefit analysis. The external world constitutes the institutional (rule) structure that influences the internal world of agent decision-making. Included in the external world are also material resource factors that affect agent information about the expected costs and benefits leading to corrupt behavior. Thus:

H1: The effect of corruption perception is mediated via attitudes to entrepreneurial intentions.

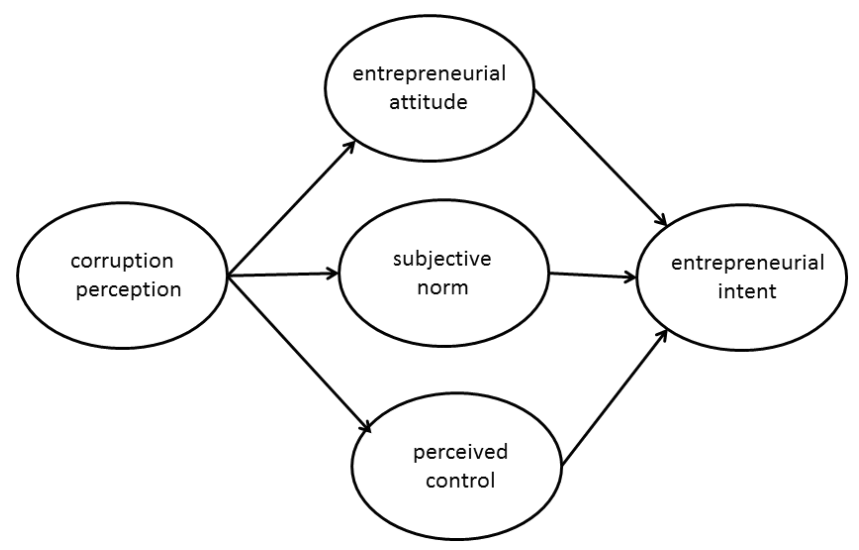

Source: Own presentation based on Ajzen, 1991.

Fig. 1. Conceptual model. 


\section{Traikova et al.}

Prevailing social norms provide the basis for social approbation and support for entrepreneurial initiatives and thus, shape entrepreneurial intentions. The opinion of family and close friends is considered to be of high importance, especially in a traditional rural setting (Kalantaridis and Bika, 2006). Beliefs that important peers are aware of prevailing corrupt practices, and still support the envisioned venture, fuel eventual entrepreneurial intentions. Perceived peer disapproval for the planned start-up has the opposite effect. As discussed above, corruption is "normalized" and often imprinted into the social norms in the transition economies of Central and Eastern Europe. Collectivistic cultures, such as Bulgaria, have among the most lenient social evaluation of corrupt practices (Collier, 2002). Hence:

$\mathrm{H} 2$ : The impact of corruption perception is mediated through social norms to entrepreneurial intentions.

Regarding perceived behavioral control, the mediation logic is closely related to the greasing-sanding argument. An individual's belief in their own ability to deal with various contingencies arising in the process of starting a new business are influenced by the perceived complications or shortcuts that a corrupt environment entails. For example, it may require some effort to track down the right person to bribe or the expected bribing costs might be perceived as unaffordable. Also, there is no guarantee if the bribe-taker will deliver the desired service or will defect - the bribe-giver has no control over this and can only hope the amount paid will be enough to motivate the respective gate-keeper. Should the potential entrepreneur shy away from paying bribes, this may force her or him to give up even before trying to start a business (sanding argument). But it is also possible paying a bribe is perceived as an option to circumvent the otherwise restrictive legal requirements, for example to obtain a permit, license, or registration without completely fulfilling the official requirements, thus encouraging entrepreneurial intentions (greasing argument). The level of perceived behavioral control is affected by the perceived pervasiveness and arbitrariness of corruption. The pervasiveness of corruption is the average likelihood of encountering a bribery request in the business interactions, whereas the arbitrariness of corruption is the degree of ambiguity associated with the likelihood of gaining agreed upon favorable treatments in corrupt transactions (Cuervo-Cazurra, 2008). The higher the pervasiveness of corruption, the higher are its expected costs. The higher the arbitrariness of corruption, the higher is the ambiguity, and hence, the lower the level of perceived behavioral control over the intended entrepreneurial initiative. Formally:

H3: The impact of corruption perception is mediated via PBC to entrepreneurial intentions.

\section{Methodology}

\subsection{Sample and data collection}

The paper presents a quantitative case study (Bryman, 2012). Our sample reflects a specific and usually under-researched farmer population, and the respondents' non-farm 
entrepreneurial intentions. Although farm activities are often characterized by a low level of commercialization, farmers may seek to diversify their income risk by gaining access to the rural non-farm economy. This puts entrepreneurship in the rural non-farm sector into the focus. Similar to the Eurobarometer database, we look at self-employment outside of the agricultural sector. Our data collection took place within a bigger collaborative project, examining Structural Change and Rural Livelihoods (refer to www.SCARLED.eu). Data were collected in 2008-2009 through a structured survey instrument in face-to-face interviews in the villages of three regions in Bulgaria (Plovdiv, Pazardjik and Burgas). The timeframe of the survey captures the period corresponding to the first years of the country's membership in the European Union, characterized by significant institutional shifts. The three survey regions were selected to cover a wide range of economic development stages and farming practices. Respondents were identified on a door-to-door principle, until predefined, regionally balanced strata was filled. Only individuals who self-identified themselves as farmers were interviewed. In total, 315 interviews were conducted. Data cleaning and removing observations with missing data rendered a usable sample of 231 observations. Because of the noticeable shrinking in sample size, we applied Little's MCAR test procedure in STATA to test for missing data bias. The test yielded a nonsignificant result (chi-square of 0.54), indicating the data are missing completely at random. Therefore, no bias because of missing values is expected. Of the 231 respondents, 52 percent were men. The youngest respondent was 18, and the oldest respondent 78 years old. The majority (54\%) reported to have secondary education, and 7 percent had a university degree. At the time of the survey, 76 percent were working full- or part-time, 13 percent were retired and 11 percent were unemployed. Although not nationally representative, this sample is suitable for an exploratory investigation of the role of corruption perceptions for the formation of start-up intentions. Still, our findings should be interpreted with caution, particularly with respect to generalizations about the drivers of entrepreneurial intentions across transition economies.

\subsection{Survey instrument}

The survey instrument covered diverse socio-economic and farm characteristics, the intention to start a non-farm business, as well as corruption perception topics. The selection of questions was agreed upon after a thorough literature review and drew on the authors' personal experience in the rural areas of Eastern Europe. The questionnaire was translated by two bilingual native speakers from English to Bulgarian and back. It was pre-tested with ten farmers. After some minor improvements in wording, interviewers were trained and sent to rural areas. Each interview took about 60-90 minutes and was conducted at the respondent's home.

To avoid common method variance problems, the questions were formulated in a simple and understandable way. Sensible questions regarding corruption were asked toward the end of the interview because they required winning the trust of the respondents first. To minimize social desirability bias, the corruption section was framed as a minor aspect within the bigger survey, which dealt mainly with typical agricultural enterprise 
issues (e.g., intensity, workload, market strategies), hence, avoided the psychologically prominent focus on the sensitive corruption issues (Podsakoff et al., 2012). The anonymity of respondents was explicitly guaranteed.

\subsection{Measures}

For our investigation, we rely strongly on perceptual measures. Perceptions are cognitive constructs, or mental representations of the environment, captured through the lens of the individual and elaborated in their minds. Perceptual measures correspond best to the nonmaterial nature of the entrepreneurial intention and have been proven robust in explaining it (Liñán et al., 2011). In the following we briefly present the operationalization of each theoretical construct. The exact wording of the questions is reported in Appendix A.

\subsubsection{Entrepreneurial intentions}

We adopted the conceptualization of Thompson (2009), who describes the entrepreneurial intention as "a self-acknowledged conviction by a person they intend to set up a new business venture and consciously plan to do so at some point in the future." Following this definition, and in line with the suggestions on how to formulate statements that capture intentions provided by Fishbein and Ajzen (2010b), we operationalized entrepreneurial intentions with the question: 'In your opinion, how likely is it that you will start a non-farm business within the next five years?' Respondents could answer on a five-point 'very unlikely-very likely' Likert-style scale. We adopted the five-year window following Krueger et al. (2000). Only about 27 percent of the surveyed respondents can be counted as intenders (rated with four or five on the 5-point Likert-style scale). This distribution poses some restrictions on the applicable analysis methods as we later discuss.

\subsubsection{Entrepreneurial attitudes}

Running a business is only one of several possible income generation strategies. Usually individuals weigh available alternatives against each other to arrive at a preference that maximizes their subjective utility (Douglas and Shepherd, 2000). Thus, we capture the entrepreneurial attitude by contrasting venture creation with other possible forms of local income generation in rural areas, such as dependent non-farm employment and farming. More specifically, following Fishbein and Ajzen (2010b) we operationalized entrepreneurial attitudes using a three-item, 5-point Likert-type scale (single factor extracted, Eigen value $=1.19$, Chronbach's Alpha $=0.71)$. The three items were averaged and summed up into an attitudinal index.

\subsubsection{Subjective norm}

For the construction of this measure, we included family, friends and colleagues as important peers. Following Ajzen (1991), we asked respondents to rate the degree of support they expect from these peer groups when it comes to the envisioned venture. Then we multiplied the respective answers with the degree to which the individual reported to care about the respective peers' opinion. The resulting product is our subjective norm variable. 


\subsubsection{Perceived behavioral control (PBC)}

Fishbein and Ajzen (2010b) define PBC as the extent to which people believe they are capable of performing a given behavior. We operationalize this construct by three 5-point Likert-type items, capturing the individual's confidence of being able to handle all possible obstacles accompanying a start-up (single factor extracted, Eigen value $=1.94$, Chronbach's Alpha $=0.87$ ). Again, the three averages are summed up into an index.

\subsubsection{Corruption perception}

We could not identify a comparable corruption perception measure, developed for the use among the rural population of potential entrepreneurs in a transition country. Drawing on the literature (Blagojević and Damijan, 2013; Budak and Rajh, 2014) and our own previous fieldwork in the region, we constructed the corruption perceptions scale as consisting of seven 5-point Likert-type items, covering aspects potentially important for the intention to found a venture in a corrupt environment. After performing an exploratory factor analysis with varimax rotation and Kaiser-off criterion, we dropped two items ('Most of the businesses here have to bend the law in order to survive' and 'Here without connections one cannot run a successful business') because they loaded on a different factor. The remaining five items were grouped under the theme of seeing bribes as effective means to solve different start-up related problems, such as obtaining permits, influencing police and court decisions, receiving funds from support programs and getting more out of the privatization process. Thus, our construct can be referred to as 'bribe effectiveness perception.' The measurement scale demonstrates good internal consistency and reliability (single factor extracted, Eigenvalue $=2.30$, Cronbach's Alpha $=0.82$ ).

\subsubsection{Control variables}

We controlled for traditional socio-economic variables such as age, gender and the educational level of the potential entrepreneur (Kautonen et al., 2013; Kibler, 2012). The descriptive statistics and correlation matrix of all items entered in the regression estimations are presented in Table 1.

\subsection{Analytical strategy}

To answer how corruption perception and its manifestations are linked to the non-farm start-up intention we test for indirect (mediation) effects. The established approach for testing mediation is the procedure introduced by Baron and Kenny (1986). It is usually performed with ordinary least squares (OLS) regression, assuming a continuous dependent variable. This is not applicable to our case. In view of the ordinary scaled intention variable, an ordered logit would have been our first choice. However, ordered logit goes with a strong assumption: each of the start-up intention levels should be equally likely to occur (also known as proportional odds assumption). As reported above, less than onethird of our respondents had entrepreneurial intentions. This skewness of the dependent variable poses a clear violation of the proportional odds assumption and results in biased 
Table 1. Descriptive statistics and Spearman's correlation matrix of entrepreneurial intent, cognitive constructs and bribing perception, $\mathrm{N}=231$.

\begin{tabular}{|c|c|c|c|c|c|c|c|c|}
\hline & \multicolumn{4}{|c|}{ Descriptive Statistics } & & & & \\
\hline & Mean & SD & Min & Max & & & & \\
\hline Entrepreneurial intent & 2.23 & 1.53 & 1 & 5 & & & & \\
\hline Attitudes & 10.57 & 4.02 & 3.00 & 15.00 & & & & \\
\hline Norms & 39.76 & 16.91 & 3.00 & 75.00 & & & & \\
\hline Behavioral control & 11.32 & 4.11 & 3.00 & 15.0 & & & & \\
\hline Perceived corruption & 17.42 & 6.17 & 5.00 & 25.00 & & & & \\
\hline Female & 0.48 & 0.50 & 0.00 & 1.00 & & & & \\
\hline Education & 3.61 & 0.76 & 1.00 & 5.00 & & & & \\
\hline \multirow[t]{3}{*}{ Age } & 45.99 & 12.76 & 18.00 & 72.00 & & & & \\
\hline & \multicolumn{8}{|c|}{ Spearman's Correlation Matrix } \\
\hline & 1 & 2 & 3 & 4 & 5 & 6 & 7 & 8 \\
\hline Entrepreneurial intent & 1.00 & & & & & & & \\
\hline Attitudes & 0.48 & 1 & & & & & & \\
\hline Norms & 0.14 & 0.22 & 1 & & & & & \\
\hline Behavioral control & 0.43 & 0.51 & 0.31 & 1 & & & & \\
\hline Perceived corruption & 0.39 & 0.31 & 0.07 & 0.17 & 1 & & & \\
\hline Female & -0.01 & 0.01 & -0.14 & -0.08 & 0.00 & 1 & & \\
\hline Education & 0.21 & 0.17 & 0.08 & 0.32 & 0.21 & 0.00 & 1 & \\
\hline Age & -0.40 & 0.22 & 0.01 & -0.14 & -0.07 & 0.02 & -0.02 & 1 \\
\hline
\end{tabular}

Source: Own calculation.

Note: Bold numbers indicate significance at the 5\% level. SD: standard deviation.

estimates (Fullerton, 2009). Therefore, we chose stereotype logistic regression (slogit) (Anderson, 1984). Slogit is an extension of the ordinal logistic model and the multinominal logistic model. It is similar to the multinominal model because it also estimates the probability of being in a particular category compared to a baseline category, given a set of predictors. At the same time, it is similar to the ordinal logistic model because of its capability to respect the ordinality of the dependent variable categories rather than the nominal categories, given a set of predictors. The difference is that other than the ordinal model, slogit allows each predictor to vary across the different categories (it overcomes the limitation of proportional odds). We used the slogit procedure in Stata.

\subsection{Mediation analysis}

According to Baron and Kenny (1986), the test for mediation involves three steps. Given mediation from an independent variable $X$ through a mediator $M$ to the dependent variable $Y$, the following steps are conducted:

- Step 1: Prove that the mediator variable explains the dependent variable (regress $Y$ on $M$, and $M$ should be significant).

- Step 2: Prove that the independent variable explains the mediator (regress $M$ on $X$, and $X$ should be significant). 
- Step 3: In a model with both independent and mediator variables explaining the dependent variable, the mediator still explains the variance (regress $Y$ on $M$ and $X$ and at least $M$ must be significant - full mediation, or both $X$ and $M$ are significant - partial mediation).

Replacing $X$ with bribes effectiveness perception, $M$ with the respective intention antecedent (i.e., attitudes, norms and PBC) and $Y$ with the entrepreneurial intent variable, we performed the slogit regressions.

\subsection{Results}

The results from our mediation testing are presented in Table 2. In the first step of the Baron-Kenny procedure we pooled all three intention antecedents as potential mediators, mirroring the essence of the TPB. Attitudes and PBC were positively and significantly associated with entrepreneurial intentions, whereas social norms were not significant. Because norms did not explain any of the variance of the dependent variable entrepreneurial intentions, it became clear they cannot be a mediator and we refrained from conducting the next mediation test steps for this variable.

In Step 2 we tested separately if the perceived effectiveness of bribes explains the variance of attitudes and perceived control respectively. This yielded significant and positive result for attitudes and perceived control, meaning they could be mediated.

Table 2. Mediated regression estimates: Predictors of entrepreneurial intent.

\begin{tabular}{|c|c|c|c|}
\hline Step 1: $Y=f(M)$ & Dependent & Entrepreneurial Intent & Coef. (S.E.) \\
\hline & & Attitudes & $0.37(0.09)^{* * *}$ \\
\hline & & Norms & $-0.00(0.01)$ \\
\hline & & Perceived control & $0.35(0.10)^{* * *}$ \\
\hline \multirow[t]{2}{*}{ Step 2a: $X=f(M)$} & Dependent & Attitudes & \\
\hline & & Perceived corruption & $0.17(0.04)^{* * *}$ \\
\hline \multirow[t]{2}{*}{ Step 2b: $X=f(M)$} & Dependent & Norms & \\
\hline & & Perceived corruption & Not applicable \\
\hline \multirow[t]{2}{*}{ Step 2c: $X=f(M)$} & Dependent & Perceived control & \\
\hline & & Perceived corruption & $0.07(0.04)^{* * *}$ \\
\hline \multirow[t]{7}{*}{ Step 3: $Y=f(X, M)$} & & Entrepreneurial intent & \\
\hline & & Perceived control & $0.28(0.09)^{* * *}$ \\
\hline & & Perceived corruption & $0.19(0.04) * * *$ \\
\hline & & Female & $0.07(0.44)$ \\
\hline & & Education & $0.26(0.34)$ \\
\hline & & Age & $-0.10(0.02)^{* * *}$ \\
\hline & & ion fun & $\operatorname{chi}^{2}(d f=7)=$ \\
\hline
\end{tabular}

Source: Own calculation.

Note: Baron-Kenny test for mediation, slogit procedure $(n=231)$; *significant at $10 \%$; ** significant at $5 \%$, *** significant at $1 \%$ level. 


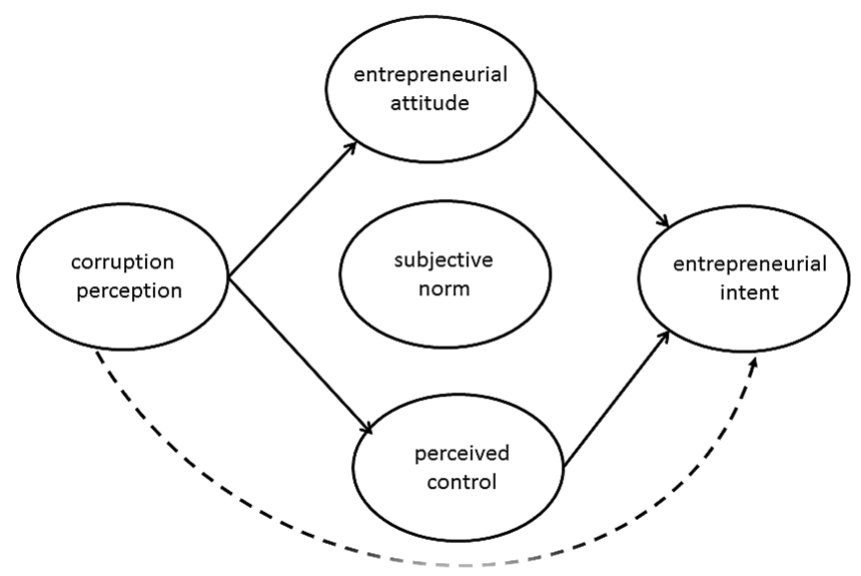

Source: Own presentation.

Fig. 2. Results of mediated regression model.

In Step 3 corruption perception (as mediated variable) and attitude, and perceived control (as potential mediators) were included as explanatory variables for start-up intentions. All regressors were significant and positive, indicating the presence of partial mediation. This implies there is both a direct and indirect effect of the perceived effectiveness of bribing on start-up intentions. The finding is robust on inclusion of norms, as well as controls (Table 2 above, Step 3). Thus, H1 and H3 received empirical support, whereas $\mathrm{H} 2$ failed to do so. Figure 2 summarizes our empirical findings.

\section{Discussion}

This study deepens our understanding of the mechanisms through which institutional background factors (and particularly perceived corruption in a post-socialist rural context) influence the formation of start-up intentions. Our principal findings are discussed below.

\subsection{Perceived corruption and attitudes}

The results from our mediated model (Table 2, Step 3) show not only that attitudes translate corruption perceptions into entrepreneurial intentions, but also that the mediation has a positive sign - more pronounced perceived bribe effectiveness is associated with a higher degree of attractiveness of the envisioned ventures. This in turn is linked with a stronger entrepreneurial intent. Succinctly put, the perception of effective bribing practices increases the desirability of an envisioned venture. This is in line with the results of Melgar et al. (2010) who found that corruption perception levels are higher among self-employed.

The link between attitude and corruption may be related to the cultural idiosyncrasies of post-socialist societies, which are generally more lenient toward corruption (Collier, 2002). As we stated in the introduction, high levels of perceived corruption may be 
associated with opportunities to engage in unproductive entrepreneurial activity, thus increasing its perceived desirability and encouraging entrepreneurial intentions (Baumol, 1990). One may further surmise what kind of ventures in the rural areas of Bulgaria (the context of our study) become attractive if an act of bribery helps circumvent the law. The examples provided below cover the whole spectrum from the partly informal to the downright illegal business activities. Circumventing the official permits system allows to formally register a business without following the usual formal requirements and shift the cost-benefits ratio to maximum advantage. An example could be obtaining a permit for a restaurant without having to fulfil all the hygiene and construction requirements. The shortcuts increase expected profit by lowering the start-up and operating costs and shortening the time until break-even. Of course, one has to offset the bribe against the presumable cost cutting. Further, bribery can allow an enterprising individual to tunnel funds from public support programs or to privatize state assets at a fraction of their fair market value. Influencing the selection procedures by bribes here would result in suboptimal allocation of public resources. Another possible way for improving the entrepreneur's income situation in the short run is to pay "envelope" wages or even opt for complete informality (Williams, 2013). The spectrum of possible business opportunities turns darker when one thinks of how bribes can be used to neutralize law enforcement by the police and/or the judiciary. In that scenario, clearly illegal activities can turn attractive and trigger entrepreneurial efforts (McElwee, 2013). Examples include harvesting wood in a protected national park, selling counterfeit products, producing and selling drugs, or even running prostitution rings. All of these opportunities appear more rewarding and less risky if bribes are perceived as effective and reliable (as the post-socialist social norm suggests) and rewarded with a positive attitude toward it.

\subsection{Perceived corruption and behavioral control}

Perceived behavioral control also partially mediates corruption perceptions. The popular argument that corrupt practices are used to get things done (Dreher and Gassebner, 2013; Méon and Weill, 2010) could be confirmed, giving support to the 'greasing' argument. This indicates that at the very first stage of the entrepreneurship process, individuals might have some idea of how they could handle the anticipated start-up challenges, and this idea, per our data, relates to bribing. The prevailing belief is that bribes will do when one needs to obtain a permit, to influence the courts, to solve problems with police, or to receive funds through a support program. All these practices mirror specific institutional aspects of the transitional context, which are relevant for founding a new venture. The findings are in line with those of Krasniqi and Desai (2016). Given that the national legislation in our case country is harmonized with the EU legal framework, it appears the weak rule of law coupled with the inherited distrust in the state allow informal institutions to 'take over' at the stage of cost-benefit calculation. The finding is robust on including traditional control variables such as age, gender and educational level (Table 2, Step 3). Taken together, the mediated effect of the perceived effectiveness of bribing through attitudes and behavioral control on entrepreneurial intentions strongly suggests that when the perceived 
effectiveness of bribing is high, entrepreneurial initiatives are perceived as both more desirable and more feasible.

\subsection{Perceived corruption and norms}

Although both attitudes and perceived behavioral control were significantly and positively associated with entrepreneurial intentions, it is interesting to note that norms, measured as the perceived support from important peers, were not predictive of the formation of startup plans. Our result is not without precedent in the TPB literature (Armitage and Conner, 2001). We also tested alternative, simpler measures of norms as suggested by Heuer and Liñán (2013), using only the measures of expected support from important peers (not reported here because of space constraints and available from the authors upon request), with substantively the same results.

\subsection{Boundaries, limitations and directions for future research}

Like most empirical research, our study has boundaries and limitations that need to be borne in mind when considering its implications. First, because of the case study character of the investigation, we rely on a relatively small sample, which should not be seen as representative for the case country or generalizable to other post-socialist economies. Moreover, we focus on a very particular population group, the farmer and his/her intent to start a non-farm business. Contrasting the perceptions of the urban population and of developed country respondents would be desirable, as well as comparing farm- with nonfarm business start-up intentions. Second, regardless of the causation direction suggested by the theory, we cannot claim causation because of the cross-sectional character of our data. Any statements implying effects or impact should be treated with caution. Third, our operationalization of the corruption perception construct focused on bribing, but bribing is just one of many facets of corruption. More explorative research is needed to fine-tune the measurement of this understudied background factor. Possible extensions could include, for example, the issues of legitimacy and reliance on personal contacts.

\subsection{Summary, implications and conclusions}

In sum, the paper makes a threefold contribution. First, we add to the 'sanding-greasing' discussion on the ex-ante effect of corruption by extending the greasing argument from 'getting things done' once business operations have started, to 'choosing a business to chase' when the start-up decision is made. Second, we anchor corruption perception as a background factor, mediated through the perceptions for desirability, normative pressure and feasibility, thus extending TPB by looking at some of the background factors affecting its key mechanisms. Third, our exploratory case study provides rare empirical evidence of the profound effect of informal social practices on the decision to start a business in transition economies. Our findings suggest attitudes and perceived control partially mediate corruption perceptions' effect on entrepreneurial intentions. This is important, 
because the perception of a corrupt environment influences how business opportunities are recognized and enacted.

Despite the prevailing corruption norm, not all people are eager to bribe in postsocialist societies. Individuals with promising start-up ideas, but with aversion toward the bribing act, may fall out of the pool of potential business starters and abandon what otherwise would have potentially brought growth and jobs. One should keep in mind those with start-up intentions strengthened by bribes' effectiveness perception are not necessarily the ones with the most sustainable and productive (in Baumol's (1990) sense) business ideas.

Our study offers important insights for public policy. The perception that corruption is effective seems to fuel entrepreneurial intentions of farmers seeking to tap non-farm income sources in rural Bulgaria. This is worrying because, as stated above, by rendering some otherwise inaccessible business opportunities attractive in a corrupt context, entrepreneurial talent also is likely to be channeled into socially undesirable, unproductive activities. Because informal institutions are known to be rather stable over time, it appears of crucial importance for policy to embrace long-term and consequent anti-corruption measures, overcoming the turbulence of elections and government changes. If potential entrepreneurs react to the perceived effectiveness of corruption, policy should design measures that will decrease the pay-offs and reliability of bribing. With this exploratory study, we start a conversation about corruption perceptions and entrepreneurial intentions. Thus, it is our hope other researchers will join this important discussion.

\section{Appendix A. Variables Wording}

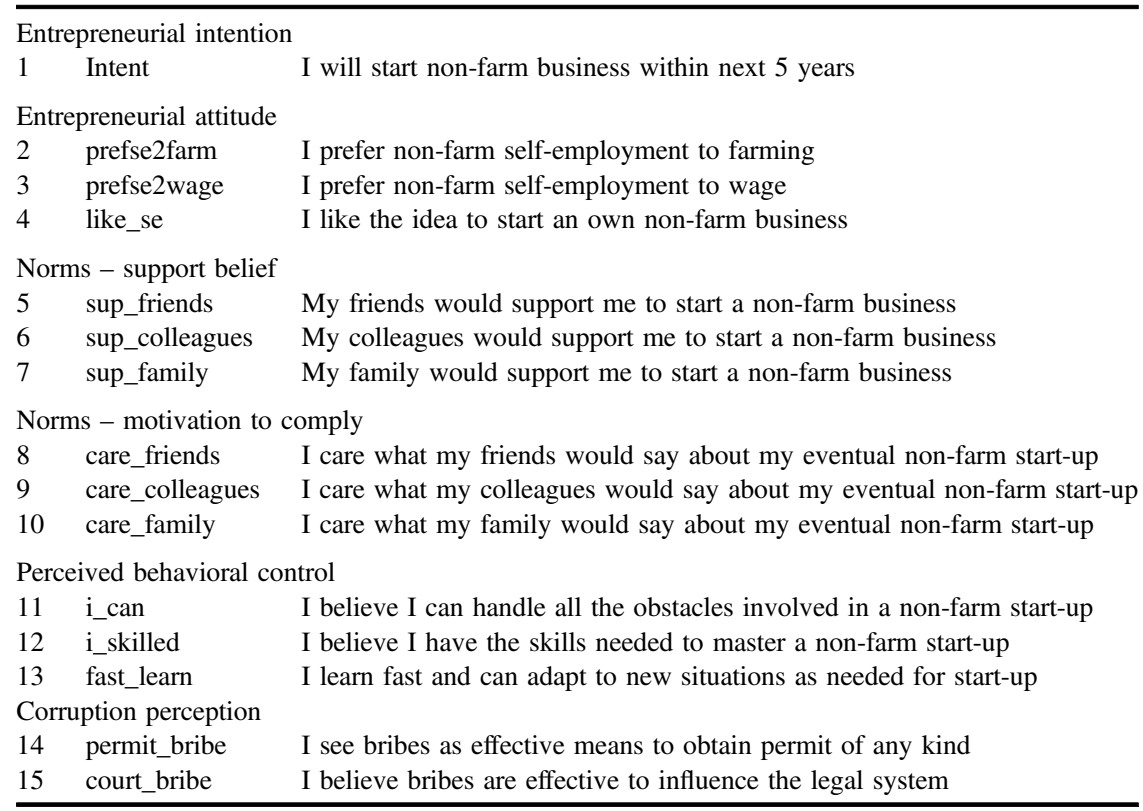


Appendix A. (Continued)

\begin{tabular}{lll}
\hline 16 & bend_law & Most of the businesses here have to bend the law in order to survive \\
17 & contacts_need & Here without connections one cannot run a successful business \\
18 & priv_bribe & Through bribes one can effectively influence the privatization process \\
19 & police_bribe & Bribes are effective to solve problems with police \\
20 & funds_bribe & Bribes are effective for obtaining public funding
\end{tabular}

Note: All variables are measured by 5-point Likert-type scales with 3 as the neutral anchor. We use a "very unlikely-very likely" rating for the intentions variable, and a 'fully-agree-fully disagree' rating for the explanatory variables.

\section{References}

Aidis, R, S Estrin and T Mickiewicz (2008). Institutions and entrepreneurship development in Russia: A comparative perspective. Journal of Business Venturing, 23(6), 656-72.

Aidt, TS (2003). Economic analysis of corruption: A survey. The Economic Journal, 113(491), F632-F652.

Ajzen, I (1991). The theory of planned behavior. Organizational Behavior and Human Decision Processes, 50, 179-211.

Anderson, JA (1984). Regression and ordered categorical variables. Journal of the Royal Statistical Society, Series B (Methodological), 46(1), 1-30.

Armitage, CJ and M Conner (2001). Efficacy of the theory of planned behavior: A meta-analytic review. British Journal of Social Psychology, 40, 471-99.

Ashforth, BE and V Anand (2003). The normalization of corruption in organizations. Research in Organizational Behavior, 25, 1-52.

Baron, RA and DA Kenny (1986). The moderator-mediator variable distinction in social psychological research: Conceptual, strategic and statistical considerations. Journal of Personality and Social Psychology, 51(6), 1173-82.

Baumol, WJ (1990). Entrepreneurship: Productive, unproductive and destructive. The Journal of Political Economy, 98(5), 893-921.

Blackburn, K, N Bose and M Emranul Haque (2006). The incidence and persistence of corruption in economic development. Journal of Economic Dynamics and Control, 30(12), 2447-67.

Blagojević, S and JP Damijan (2013). The impact of corruption and ownership on the performance of firms in Central and Eastern Europe. Post-Communist Economies, 25(2), 133-58.

Bryman, A (2012). Social Research Methods (4th ed.). Oxford: Oxford University Press.

Budak, J and E Rajh (2014). Corruption as an obstacle for doing business in the Western Balkans: A business sector perspective. International Small Business Journal, 32(2), 140-57.

Campos, NF, R Dimova and A Saleh (2010). Whiter corruption? A quantitative survey on the literature on corruption and growth. [ftp.iza.org/dp5334.pdf].

Cieślik, J and A van Stel (2014). Comparative analysis of recent trends in private sector development in CEE transition economies. Entrepreneurship Research Journal, 4(2), 205-35.

Collier, MW (2002). Explaining corruption: An institutional choice approach. Crime, Law and Social Change, 38(1), 1-32.

Cuervo-Cazurra, A (2008). Better the devil you don't know: Types of corruption and FDI in transition economies. Journal of International Management, 14(1), 12-27.

Dejardin, M and H Laurent (2014). Greasing the Wheels of Entrepreneurship? A Complement According to Entrepreneurial Motives (Vol. 2014/2). Namur: CERPE.

Dimitrova-Grajzl, V, P Grajzl and AJ Guse (2012). Trust, perceptions of corruption and demand for regulation: Evidence from post-socialist countries. The Journal of Socio-Economics, 41(3), 292-303. 
Douglas, EJ and DA Shepherd (2000). Entrepreneurship as a utility maximizing response - Entrepreneurial management. Journal of Business Venturing, 15, 231-51.

Dreher, A and M Gassebner (2013). Greasing the wheels? The impact of regulations and corruption on firm entry. Public Choice, 155(3-4), 413-32.

Engle, RL, C Schlaegel and N Dimitriadi (2011). Institutions and entrepreneurial intent: A crosscountry study. Journal of Developmental Entrepreneurship, 16(02), 227-50.

Estrin, S, J Korosteleva and T Mickiewicz (2013). Which institutions encourage entrepreneurial growth aspirations? Journal of Business Venturing, 28(4), 564-80.

Estrin, S and T Mickiewicz (2011). Entrepreneurship in transition economies: The role of institutions and generational change. In The Dynamics of Entrepreneurship: Evidence from the Global Entrepreneurship Monitor Data, M Minniti (ed.), 181-208. Oxford: Oxford University Press.

European Commisson (2015). Funding opportunities under the Common Agricultural Policy. [ec. europa.eu/agriculture/cap-funding/funding-opportunities/index_en.htm].

Fishbein, M and I Ajzen (2010a). Background factors and origins of beliefs. In Predicting and Changing Behavior, M Fishbein (ed.), 221-53. New York: Psychology Press.

(2010b). Predicting and Changing Behavior. The Reasoned Action Approach. New York: Psychology Press.

Fullerton, AS (2009). A conceptual framework for ordered logistic regression models. Sociological Methods and Research, 38(2), 306-47.

Griffiths, MD, J Kickul and AL Carsrud (2009). Government bureaucracy, transactional impediments and entrepreneurial intentions. International Small Business Journal, 27(5), 626-45.

Grodeland, ÅB and A Aasland (2011). Fighting corruption in public procurement in post-communist states: Obstacles and solutions. Communist and Post-Communist Studies, 44(1), 17-32.

Harbi, SE and AR Anderson (2010). Institutions and the shaping of different forms of entrepreneurship. Journal of Socio-Economics, 39(3), 436-44.

Hellman, JS, G Jones, D Kaufmann and M Schankerman (2000). Measuring governance, corruption, and state capture - how firms and bureaucrats shape the business environment in transition economies. [ideas.repec.org/p/wbk/wbrwps/2312.html].

Heuer, A and F Liñán (2013). Testing alternative measures of subjective norms in entrepreneurial intention models. International Journal of Entrepreneurship and Small Business, 19(1), $35-50$.

Kalantaridis, C and Z Bika (2006). In-migrant entrepreneurship in rural England: Beyond local embeddedness. Entrepreneurship and Regional Development, 18(2), 109-31.

Kautonen, T, Mv Gelderen and E Tornikoski (2013). Predicting entrepreneurial behaviour: A test of the Theory of Planned Behavior. Applied Economics, 45(6), 697-707.

Kibler, E (2012). Formation of entrepreneurial intentions in a regional context. Entrepreneurship and Regional Development, (3-4), 293-323.

Krasniqi, BA and S Desai (2016). Institutional drivers of high-growth firms: Country-level evidence from 26 transition economies. Small Business Economics, 47(4), 1075-94.

Krueger, NF, MD Reilly and AL Carsrud (2000). Competing models of entrepreneurial intentions. Journal of Business Venturing, 15(5-6), 411-32.

Lawrence, TB, C Hardy and P Nelson (2002). Institutional effects of interorganizational collaboration: The emergence of proto-institutions. The Academy of Management Journal, 45(1), 281-90.

Lee, WS and C Guven (2013). Engaging in corruption: The influence of cultural values and contagion effects at the microlevel. Journal of Economic Psychology, 39(0), 287-300.

Levy, D (2007). Price adjustment under the table: Evidence on efficiency-enhancing corruption. European Journal of Political Economy, 23(2), 423-47. 
Liñán, F and A Fayolle (2015). A systematic literature review on entrepreneurial intentions: Citation, thematic analyses and research agenda. International Entrepreneurship and Management Journal, 1-27.

Liñán, F, FJ Santos and J Fernández (2011). The influence of perceptions on potential entrepreneurs. International Entrepreneurship and Management Journal, 7(3), 373-90.

Manev, I and TS Manolova (2010). Entrepreneurship in transitional economies: Review and integration of two decades of research. Journal of Developmental Entrepreneurship, 15(1), 69-99.

McElwee, G (2013). Confronting social constructions of rural criminality: A case story on 'illegal pluriactivity' in the farming community. Sociologia Ruralis, 53(1), 112-34.

Melgar, N, M Rossi and TW Smith (2010). The perception of corruption. International Journal of Public Opinion Research, 22(1), 120-31.

Méon, PG and K Sekkat (2005). Does corruption grease or sand the wheels of growth? Public Choice, 122, 69-97.

Méon, PG and L Weill (2010). Is corruption an efficient grease? World Development, 38(3), 244-59.

Moriano, JA, M Gorgievski, M Laguna, U Stephan and K Zarafshani (2012). A cross-cultural approach to understanding entrepreneurial intention. Journal of Career Development, 39(2), $162-85$.

North, D (1990). Institutions, Institutional Change and Economic Performance. Cambridge, MA: Harvard University Press.

NSI (2009). Statistical Yearbook. Sofia, Bulgaria.

Olken, BA (2009). Corruption perceptions vs. corruption reality. Journal of Public Economics, 93(7-8), 950-64.

Podsakoff, PM, SB MacKenzie and NP Podsakoff (2012). Sources of method bias in social science research and recommendations on how to control it. Annual Review of Psychology, 63(1), 539-69.

Pring, C (2016). People and corruption: Europe and Central Asia. [www.transparency.org/whatwedo/ publication/7493].

Reinikka, R and J Svensson (2004). Local Capture: Evidence from a Central Government Transfer Program in Uganda. The Quarterly Journal of Economics, 119(2), 679-705.

Rock, MT and H Bonnett (2004). The comparative politics of corruption: Accounting for the East Asian paradox in empirical studies of corruption, growth and investment. World Development, 32(6), 999-1017.

Scott, WR (1995). Institutions and Organizations. Thousand Oaks, CA: Sage.

Stenholm, P, ZJ Acs and R Wuebker (2013). Exploring country-level institutional arrangements on the rate and type of entrepreneurial activity. Journal of Business Venturing, 28(1), 176-93.

Stoyanov, A, R Stefanov and B Velcheva (2014). Bulgarian Anti-Corruption Reforms: A Lost Decade? [www.csd.bg/artShow.php?id=16904].

Thompson, ER (2009). Individual entrepreneurial intent: Construct clarification and development of an internationally reliable metric. Entrepreneurship Theory and Practice, 33(3), 669-94.

Timofeyev, Y and HD Yan (2013). Predicaments of entrepreneurship in transitional Russia. International Journal of Entrepreneurship and Small Business, 20(1), 70-95.

Tonoyan, V, R Strohmeyer, M Habib and M Perlitz (2010). Corruption and entrepreneurship: How formal and informal institutions shape small firm behavior in transition and mature market economies. Entrepreneurship Theory and Practice, 34(5), 803-31.

van der Zwan, P, I Verheul and AR Thurik (2011). The entrepreneurial ladder in transition and nontransition economies. Entrepreneurship Research, 1(2), article 4.

Vorley, T and N Williams (2015). Between petty corruption and criminal extortion: How entrepreneurs in Bulgaria and Romania operate within a devil's circle. International Small Business Journal. 
Waterfield, B (2008). EU is funding Bulgarian mafia, finds Brussels report. [blogs.telegraph.co.uk/ news/brunowaterfield/4644557/EU_is_funding_Bulgarian_mafia_finds_Brussels_report/].

Webb, TL and P Sheeran (2006). Does changing behavioral intentions engender behavior change? A meta-analysis of the experimental evidence. Psychological Bulletin, 132(2), 249-68.

Welter, F (2011). Contextualizing entrepreneurship - Conceptual challenges and ways forward. Entrepreneurship Theory and Practice, 35(1), 165-84.

Welter, F and D Smallbone (2011). Institutional perspectives on entrepreneurial behavior in challenging environments. Journal of Small Business Management, 49(1), 107-25.

Wennekers, S, A Van Stel, M Carree and AR Thurik (2010). The relationship between entrepreneurship and economic development: Is it U-shaped? Foundations and Trends ${ }^{\circledR}$ in Entrepreneurship, 6(3), 167-237.

Williams, CC (2013). Explaining employers' illicit envelope wage payments in the EU-27: A product of over-regulation or under-regulation? Business Ethics: A European Review, 22(3), $325-40$. 